DOI: https://doi.org/10.47405/mjssh.v6i10.1092

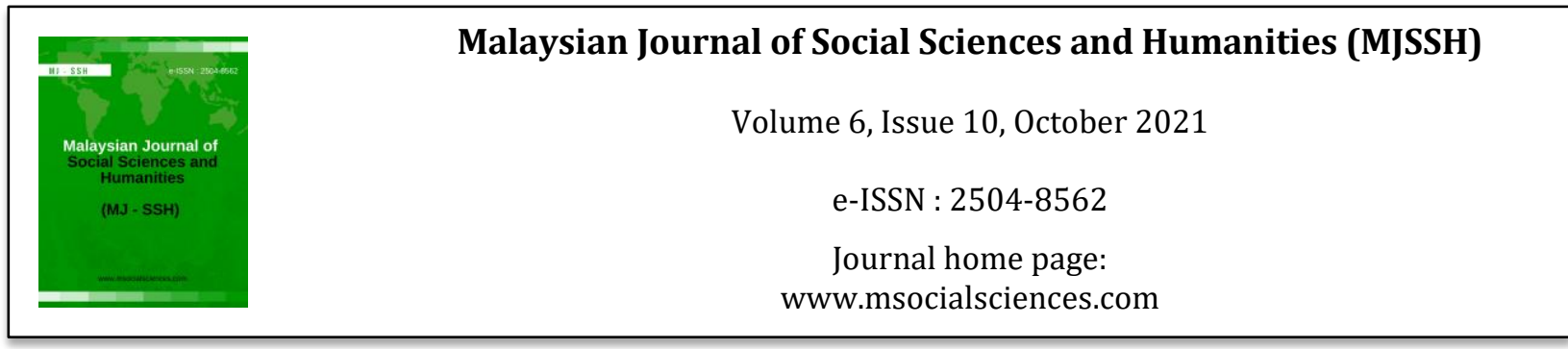

\title{
Daya Tahan dan Motivasi Pembelajaran alam Talian Semasa Pandemik Covid-19 Pelajar Kolej Universiti Islam Melaka (KUIM)
}

\author{
Nuramirah Nabila Zakaria1, Norzaini Azman'1 \\ 1Fakulti Pendidikan, Universiti Kebangsaan Malaysia (UKM), Malaysia
}

Correspondence: Nuramirah Nabila Zakaria (p103771@siswa.ukm.edu.my)

\begin{abstract}
Abstrak
Kajian ini dijalankan bagi mengenal pasti hubungan antara daya tahan dengan motivasi pelajar sepanjang pembelajaran dalam talian semasa pandemik. Kajian ini berbentuk kajian kes dengan memilih sebuah IPT iaitu KUIM sebagai satu organisasi kajian dan data dikumpulkan melalui kaedah tinjauan menggunakan borang soal selidik sebagai instrumen kajian. Data kajian adalah berbentuk kuantitatif yang dianalisis menggunakan analisis statistik deskriptif dan inferensi. Seramai 278 pelajar KUIM telah dipilih sebagai sampel kajian dengan menggunakan kaedah persampelan rawak berkelompok. Daya tahan pelajar telah diukur dengan menggunakan Soal selidik Ketahanan Kendiri (SKD) yang diterjemahkan oleh Amalia et al. (2011) dan motivasi pelajar pula diukur dengan menggunakan Soal selidik Motivated Strategies for Learning (MSLQ) oleh Pintrich et al. (1991). Dapatan kajian mendapati pelajar KUIM memiliki tahap daya tahan dan tahap motivasi yang tinggi sepanjang pembelajaran dalam talian semasa pandemik. Analisis korelasi pula menunjukkan terdapat hubungan linear positif yang kuat dan signifikan antara daya tahan dengan motivasi pelajar KUIM sepanjang pembelajaran dalam talian semasa pandemik. Hasil kajian juga mendapati terdapat perbezaan yang signifikan antara daya tahan berdasarkan faktor jantina pelajar. Namun, tidak terdapat perbezaan yang signifikan antara motivasi berdasarkan faktor jantina. Dapatan kajian ini menyokong teori bahawa semakin tinggi tahap daya tahan pelajar, semakin tinggi tahap motivasi mereka. Dapatan kajian ini wajar diambil serius oleh semua pihak khususnya IPT dalam usaha memastikan daya tahan dan motivasi pelajar sentiasa meningkat agar mereka tetap bersemangat menjalani pembelajaran secara dalam talian. Pihak bertanggungjawab juga perlu berganding bahu merangka inisiatif terbaik bagi memberikan sokongan yang sewajarnya kepada pelajar.
\end{abstract}

Kata kunci: daya tahan, motivasi, pembelajaran dalam talian, pelajar kolej universiti

\section{Resilience and Motivation During Online Learning Throughout the Covid-19 Pandemic of Students University College of Islam Melaka (KUIM)}

\begin{abstract}
This study was conducted to identify the relationship between resilience and student motivation throughout online learning during the pandemic. Using a case study, data was collected through questionnaires distributed to a sample in a private higher education institution, which is KUIM. A cluster random sampling method was utilized to select the 278 respondents for the study sample. Student resilience was measured using the Self-Resilience Questionnaire (SKD) translated by Amalia et al. (2011) and student motivation was measured using the Motivated Strategies for Learning Questionnaire (MSLQ) by Paul Pintrich et al. (1991). The data was analyzed using descriptive and
\end{abstract}


inferential statistics. Findings of the study show that KUIM students have a high level of resilience and motivation throughout online learning during the pandemic. Analysis of correlation indicate a strong and significant positive linear relationship between resilience and motivation. The results of the study also found significant differences between level of resilience and gender, but no significant differences level of motivation and gender. Overall, it can be inferred that students with higher level of resiliency have high motivation. Therefore, it is important that students are motivated and resilient to academic adversity during the pandemic and that the higher education institution concerned should better understand what makes students resilient and motivated in the face of adversity and what initiatives can be used to help develop resilience as well as motivate students to achieve academic success.

Keywords: resilience, motivation, online learning, university college students

\section{Pengenalan}

Dunia telah digemparkan dengan wabak virus Covid-19 yang telah melanda kepada hampir semua negara. Rutin harian manusia terjejas disebabkan oleh peningkatan kes jangkitan virus Covid-19 hari demi hari. Bagi membendung penularan wabak yang lebih serius, penjagaan kebersihan telah dititikberatkan sehinggalah berlakunya penguatkuasaan pergerakan iaitu Perintah Kawalan Pergerakan (PKP) oleh kebanyakan negara di dunia termasuklah Malaysia. Banyak sektor perkhidmatan yang telah terjejas setelah penguatkuasaan PKP termasuk sektor pendidikan. Sektor pendidikan termasuk peringkat tadika, sekolah rendah, sekolah menengah, kolej dan universiti atau mana-mana institusi berkaitan pendidikan perlu menggunakan alternatif berbeza bagi memastikan proses dan matlamat pendidikan dapat dicapai. Hampir kesemua peringkat pendidikan telah menggunakan pembelajaran dalam talian sebagai alternatif kepada pembelajaran tradisional.

Pembelajaran dalam talian bukanlah suatu perkara yang baharu namun telah lama diperkenalkan. Terdapat pelbagai platform yang boleh digunakan oleh guru dan pelajar dalam aktiviti pembelajaran seperti Google Classroom, Google Meet, Zoom dan lain-lain sepanjang tempoh PKP (Muhammad Izzat et al., 2020). Sepanjang menjalani proses pengajaran dan pembelajaran dalam talian, motivasi dan daya tahan diri merupakan aspek penting yang perlu ada dalam diri pelajar agar mereka sentiasa bersemangat dan komited serta tidak mudah putus asa. Walaupun banyak kajian mengenai daya tahan dan motivasi telah dijalankan oleh pengkaji sebelum ini (Irmohizam \& Hussin, 2016; Aisyah et al., 2017; Nor Fadilah \& Siti Mistima, 2020), namun kajian mengenai daya tahan dan motivasi pelajar semasa pandemik Covid-19 masih terhad. Selain itu, terdapat keperluan bagi melihat tahap daya tahan dan motivasi pelajar memandangkan pandemik yang berpanjangan ini berisiko menjadikan pelajar berada dalam fasa kelesuan (burn out). Letchumanan et al. (2019) dalam kajian mereka mendapati motivasi dapat merangsang pembelajaran individu sementara keterlibatan aktif dalam proses pembelajaran mampu meningkatkan motivasi pelajar. Manakala, kajian Burcu dan Derya (2020) semasa pandemik Covid-19 di Turki pula menunjukkan pelajar lelaki, pendidik, graduan universiti dan kumpulan yang tidak mempunyai masalah kesihatan mental mempunyai ketahanan psikologi lebih tinggi. Selain itu, terdapat perkaitan antara motivasi dengan daya tahan yang mana motivasi diperlukan dalam membentuk pelajar berdaya tahan dan motivasi perlu dipertingkatkan dari semasa ke semasa (Barbara, 2018).

Kajian ini bertujuan untuk mengenal pasti hubungan antara daya tahan dengan motivasi pelajar sepanjang pembelajaran dalam talian semasa pandemik. Benson (2002) mendefinisikan daya tahan sebagai ciri-ciri individu yang stabil dan mempunyai kekuatan untuk bangkit semula setelah menghadapi kesukaran. Manakala, motivasi merupakan satu bentuk dorongan untuk seseorang dalam melakukan sesuatu perkara bagi memenuhi keperluan dan kehendak mereka (Sharifah, 2005). Terdapat tiga objektif khusus yang dikaji dalam kajian ini. Objektif kajian ini adalah: (i) mengenal pasti tahap daya tahan dan motivasi pelajar KUIM semasa pembelajaran dalam talian sepanjang pandemik; (ii) mengenal pasti perbezaan tahap daya tahan dan motivasi berdasarkan jantina dalam kalangan pelajar KUIM semasa pembelajaran dalam talian sepanjang pandemik, dan (iii) mengenal pasti hubungan 
antara daya tahan dengan motivasi dalam kalangan pelajar KUIM semasa pembelajaran dalam talian sepanjang pandemik.

Artikel ini mempunyai empat bahagian. Bahagian pertama mensintesiskan hasil kajian literatur berkaitan dengan daya tahan dan motivasi. Bahagian kedua menerangkan metodologi kajian dan kaedah yang digunakan untuk mengumpul dan menganalisis data. Seterusnya, hasil kajian akan dibincangkan berasaskan dapatan kajian lepas sebelum diikuti oleh bahagian terakhir yang membincangkan implikasi kajian serta mencadangkan beberapa kajian lanjutan mengenai daya tahan dan motivasi pelajar di IPT.

\section{Sorotan Literatur}

\section{Pembelajaran dalam talian}

Pembelajaran secara dalam talian merupakan satu platform pendidikan bagi menggantikan pertemuan bersemuka antara pendidik dengan pelajar lebih-lebih lagi semasa pandemik ini (Rios, 2019). Bagi membendung penularan wabak Covid-19, pelaksanaan pembelajaran secara dalam talian juga banyak memberi manfaat kepada semua pihak terutamanya pelajar dalam meningkatkan kemahiran menggunakan teknologi terkini dan membentuk pemikiran yang kritis dan kreatif dalam diri pelajar (Munirah et al., 2021). Walaupun pelajar menghadapi pelbagai kekangan seperti gangguan rangkaian internet dan masalah keperluan peranti pembelajaran, ia bukanlah satu halangan kepada pelajar dalam mengikuti kaedah pembelajaran secara dalam talian (Siti Nursyahidah et al., 2020). Demi memastikan keberkesanan pembelajaran secara dalam talian, daya tahan dan motivasi pelajar perlu dititikberatkan agar pelajar terus bersemangat meneruskan perjuangan menimba ilmu.

\section{Daya tahan}

American Psychological Association (2014) mendefinisikan daya tahan sebagai satu proses bangkitan semula (bouncing back) daripada pengalaman yang mencabar dan kemampuan individu beradaptasi dengan baik terhadap cabaran, trauma, tragedi, ancaman atau sumber tekanan yang signifikan. Pelajar yang berdaya tahan ialah pelajar yang dapat menilai, mengatasi dan memperbaiki diri ke arah lebih baik (Harsela et al., 2020). Keyakinan dalaman diri untuk berdaya tahan dapat memupuk diri mereka agar berkebolehan berhadapan dengan tugasan yang sukar. Menurut Salehudin dan Zakaria (2017), pelajar tidak mampu menguasai kemahiran berfikir aras tinggi, tidak dapat menyelesaikan masalah dengan menggunakan inisiatif sendiri, penguasaan konsep yang lemah dan potensi diri tidak dapat dikembangkan untuk berfikir secara kritis dan kreatif sekiranya ketahanan diri tergugat. Daya tahan dilihat dapat membantu individu menghadapi tekanan dengan membangkitkan semula semangat dan menyesuaikan diri ketika berhadapan dengan persekitaran yang sukar lebih-lebih lagi semasa pandemik Covid-19 yang memberi kesan kepada individu dan masyarakat terutamanya kepada pelajar.

Richardson (2002) telah membincangkan tiga peringkat daya tahan iaitu di peringkat pertama, daya tahan dilihat sebagai aspek keselamatan khususnya kepada golongan muda yang berhadapan situasi hidup berisiko tinggi. Peringkat kedua melibatkan bagaimana individu mencapai kualiti daya tahan sementara peringkat ketiga melibatkan bagaimana aspek motivasi dalaman individu dalam berdaya tahan saat berdepan dengan kesusahan. Justeru, daya tahan melibatkan pelbagai tahap keupayaan yang dimiliki seseorang untuk tetap cekal dalam menghadapi situasi yang sukar. Oleh itu, kajian ini cuba mengukur tahap keupayaan pelajar berdaya tahan dengan kesukaran sepanjang pembelajaran secara dalam talian.

Beberapa kajian lepas telah menunjukkan bahawa pelajar IPT mempunyai tahap daya tahan yang berbeza dan pelajar yang mempunyai daya tahan yang tinggi mampu mengurangkan masalah psikologi (Burcu \& Derya, 2020; Warren \& Hale, 2020). Kajian oleh Burcu dan Derya (2020) ke atas 518 orang pelajar IPT di Turki dengan menggunakan borang soal selidik secara dalam talian mendapati responden daripada kalangan pelajar lelaki dan kumpulan yang tidak mempunyai masalah kesihatan mental mempunyai daya tahan yang tinggi. Seterusnya, kajian oleh Warren dan Hale (2020) yang mengenal 
pasti tahap daya tahan pelajar IPT di Amerika Syarikat mendapati faktor jantina mempunyai perkaitan dengan tahap daya tahan. Dapatan kajian ini merumuskan bahawa pelajar lelaki dan pelajar perempuan mempunyai daya tahan yang berbeza dan pelajar lelaki mempunyai tahap daya tahan yang lebih tinggi berbanding pelajar perempuan.

\section{Motivasi}

Motivasi adalah dorongan dalaman dan luaran dalam diri individu yang mendorong individu tersebut untuk mencapai sesuatu tujuan (Weiner, 1990). Motivasi juga didefinisikan sebagai daya penggerak utama seseorang yang melibatkan proses membangkit, mengekal dan mengawal minat (Bernard, 1965; Kamarudin, 1993). Dalam erti kata lain, definisi motivasi merujuk kepada perubahan tenaga dalam diri atau peribadi seseorang yang akan menimbulkan perasaan atau tindakan untuk mencapai matlamat (Hamalik, 1992). Pelajar yang bermotivasi tinggi dapat mengekalkan minat terhadap pembelajaran kerana mempunyai dorongan yang kuat (Zaliza \& Zaitul, 2013). Hal ini menunjukkan tahap motivasi pelajar mampu mempengaruhi sejauh mana kesanggupan pelajar untuk menumpukan tenaga dan usaha untuk belajar serta melaksanakan sesuatu tugasan akademik (Wina, 2010).

Beberapa kajian lepas telah dijalankan bagi melihat motivasi pelajar sepanjang pembelajaran dalam talian semasa pandemik Covid-19 (Abdul Aziz \& Aida, 2020; Ida et al., 2020). Selaras dengan teori kepentingan motivasi, motivasi pelajar IPT didapati sangat penting dalam memastikan mereka bersedia mengikuti pembelajaran secara dalam talian. Sekiranya pelajar bersedia dari segi fizikal, mental dan kelengkapan yang cukup dalam memastikan kelancaran proses pengajaran dan pembelajaran, secara tidak langsung dapat membantu meningkatkan motivasi untuk belajar (Zaliza \& Zaitul, 2014; Mohd Zaki \& Mohd Firdaus, 2018). Selain itu, kajian lepas juga menunjukkan terdapat hubungan yang signifikan antara kesediaan pelajar dengan motivasi pelajar terhadap pembelajaran secara dalam talian (Abdul Aziz \& Aida, 2020). Pembelajaran secara dalam talian yang menggunakan teknologi digital juga dilihat memberi kesan yang positif terhadap motivasi pelajar sepanjang pandemik (Ida Faridah et al., 2020). Hal ini disebabkan pelajar lebih bermotivasi semasa belajar sambil mengaplikasikan pembelajaran menggunakan teknologi digital. Penggunaan teknologi digital secara tidak langsung dapat meningkatkan motivasi pelajar dan membantu mereka mencapai objektif pembelajaran (Ida Faridah et al., 2020).

\section{Metod Kajian}

Kajian ini berbentuk kajian kes dengan memilih sebuah kolej universiti sebagai satu organisasi kajian. Data dikumpulkan melalui kaedah tinjauan menggunakan borang soal selidik sebagai instrumen kajian. Data kajian adalah berbentuk kuantitatif dianalisis menggunakan analisis statistik deskriptif dan inferensi. Menurut Creswell (2014), pendekatan kuantitatif menggunakan instrumen tertentu digunakan untuk menguji objektif dan hubungan antara pemboleh ubah yang diukur sehingga jumlah data terkumpul dapat dianalisis dengan menggunakan prosedur statistik.

Populasi kajian tertumpu kepada sebuah Institut Pengajian Tinggi (IPT) di Kuala Sungai Baru, Melaka. IPT ini dipilih kerana ia adalah satu-satunya institusi pengajian tinggi yang dimiliki oleh negeri Melaka. Kolej universiti yang ditubuhkan pada tahun 1996 ini juga menerapkan cara pendidikan baharu melalui gabungan pendidikan Islam, Sains dan disiplin psikologi. Dalam usaha penjenamaan semula, KUIM adalah di antara Kolej Universiti Islam swasta pertama di Malaysia yang membangunkan pengajian berfokuskan bidang psikologi di peringkat ijazah. Populasi kajian ini merujuk kepada pelajar Kolej Universiti Islam Melaka yang dipilih dari dua buah fakulti iaitu Fakulti Sains Sosial dan Fakulti Bahasa dan Pendidikan. Saiz populasi kajian ialah seramai 1004 orang pelajar. Berdasarkan jadual penentuan saiz sampel yang dicadangkan oleh Krejcie dan Morgan (1970) iaitu seramai 278 bagi 1000 orang populasi, maka sampel kajian ialah 278 pelajar. Pemilihan sampel bagi kajian ini dibuat berdasarkan persampelan rawak berkelompok. Menurut Chua (2006), persampelan rawak berkelompok sesuai dilakukan ke atas bilangan subjek yang ramai dalam populasi di mana senarai subjek tidak dapat diperoleh. Soal selidik dikongsi secara dalam talian kepada responden kajian melalui Google Form. Kaedah ini dipilih kerana terdapat kekangan dari segi urusan mengedarkan soal 
selidik secara bersemuka yang dikhuatiri boleh meningkatkan risiko jangkitan wabak Covid-19. Kebanyakan pelajar juga melaksanakan pembelajaran secara dalam talian di kediaman masing-masing.

Borang soal selidik dalam kajian ini terdiri daripada tiga bahagian. Bahagian A adalah bertujuan untuk mendapatkan maklumat latar belakang responden, Bahagian B adalah Soal selidik Ketahanan Kendiri (SKD) yang diterjemahkan oleh Amalia et al. (2011) dan Bahagian C pula adalah Motivated Strategies for Learning Questionnaire (MSLQ) oleh Pintrich et al. (1991). Soal selidik daya tahan merangkumi lima dimensi daya tahan berdasarkan lima ciri daya tahan diri yang dihuraikan oleh Wagnild dan Young (1993) iaitu kebergantungan kendiri, mempunyai makna, ketenangan fikiran dan perasaan, ketabahan dalam menghadapi kesukaran dan falsafah kesunyian dan bersendirian tidak wujud. Responden menilai setiap item berdasarkan skala likert yang terdiri daripada tahap $1=$ sangat tidak bersetuju sehingga tahap 7 = sangat bersetuju mengikut tahap persetujuan responden. Jumlah keseluruhan skor daya tahan ialah antara 25 hingga 175 mata. Terdapat enam tahap daya tahan pelajar berdasarkan jumlah skor iaitu 25 hingga $100=$ sangat rendah, 101 hingga $115=$ rendah, 116 hingga $130=$ agak rendah, 131 hingga $145=$ sederhana, 146 hingga $160=$ sederhana tinggi dan 161 hingga 175 = tinggi. Skor pada tahap yang rendah bermakna tahap daya tahan pelajar sepanjang pembelajaran dalam talian adalah rendah dan skor pada tahap yang tinggi menunjukkan tahap daya tahan pelajar sepanjang pembelajaran dalam talian adalah tinggi. Jadual 1 menunjukkan dimensi dan bilangan item bagi instrumen SKD.

Jadual 1: Dimensi dan bilangan item bagi instrumen SKD

\begin{tabular}{lll}
\hline Dimensi & Nombor item & Jumlah \\
\hline Kebergantungan kendiri & B2, B9, B13, B18, B23 & 5 \\
Mempunyai makna & B4, B6, B11, B15, B21 & 5 \\
Ketenangan fikiran dan perasaan & B7, B12, B16, B19, B22 & 5 \\
Ketabahan & B1, B10, B14, B20, B24 & 5 \\
Falsafah persendirian & B3, B5, B8, B17, B25 & 5 \\
\hline Keseluruhan daya tahan & & $\mathbf{2 5}$ \\
\hline
\end{tabular}

Soal selidik Motivated Strategies for Learning (MSLQ) mempunyai dua bahagian iaitu motivasi dan strategi pembelajaran pelajar. Soal selidik ini mengandungi 31 item yang mengukur motivasi pelajar dan 50 item untuk mengukur strategi belajar. Dalam kajian ini, pengkaji hanya menggunakan item motivasi pelajar sahaja. Terdapat enam dimensi yang diukur dalam soal selidik ini iaitu motivasi intrinsik, motivasi ekstrinsik, nilai tugasan, kawalan kepercayaan pembelajaran, efikasi kendiri pembelajaran dan prestasi dan kebimbangan ujian. Responden menilai setiap item berdasarkan skala likert yang terdiri daripada tahap $1=$ sangat tidak benar sehingga tahap $7=$ sangat benar. Jumlah keseluruhan skor motivasi ialah 31 hingga 217. Terdapat dua tahap motivasi pelajar berdasarkan jumlah skor iaitu 31 hingga 124 adalah tahap rendah dan 125 hingga 217 adalah tahap tinggi. Skor pada tahap yang rendah bermakna tahap motivasi pelajar sepanjang pembelajaran dalam talian adalah rendah dan skor pada tahap yang tinggi menunjukkan bahawa tahap motivasi pelajar sepanjang pembelajaran dalam talian adalah tinggi. Jadual 2 menunjukkan dimensi dan bilangan item bagi instrumen MSLQ.

Jadual 2: Dimensi dan bilangan item bagi instrumen MSLQ

\begin{tabular}{lll}
\hline Dimensi & Nombor item & Jumlah \\
\hline Motivasi intrinsik & C1, C16, C22, C24 & 4 \\
Motivasi ekstrinsik & C7, C11, C13, C30 & 4 \\
Nilai tugasan & C4, C10, C17, C23, C26, C27 & 6 \\
Kawalan kepercayaan pembelajaran & C2, C9, C18, C25 & 4 \\
Efikasi kendiri pembelajaran dan prestasi & C5, C6, C12, C15, C20, C21, C29, C31 & 8 \\
Kebimbangan ujian & C3, C8, C14, C19, C28 & 5 \\
\hline Keseluruhan motivasi & & $\mathbf{3 1}$ \\
\hline
\end{tabular}


Hasil ujian kebolehpercayaan terhadap 278 orang pelajar KUIM mencatatkan nilai kebolehpercayaan alpha Cronbach, a bagi soal selidik daya tahan (SKD) ialah 0.941. Dapatan ini menunjukkan soal selidik daya tahan dalam kajian ini mempunyai kebolehpercayaan yang tinggi. Kajian yang turut menyokong Soal selidik Ketahanan Kendiri mempunyai kebolehpercayaan yang tinggi ialah kajian yang dijalankan oleh Rocio et al. (2018). Kebolehpercayaan soal selidik dalam kajiannya ialah $a=$ 0.89. Sementara, soal selidik yang mengukur tahap motivasi pelajar (MSLQ) semasa pembelajaran dalam talian sepanjang pandemik juga mempunyai nilai kebolehpercayaan yang tinggi iaitu $a=0.952$. Kebolehpercayaan soal selidik MSLQ yang tinggi memperkukuhkan kajian yang dijalankan Molly et al. (2020) yang merumuskan bahawa MSLQ sesuai digunakan. Jadual 3 menunjukkan nilai Alpha Cronbach bagi instrumen SKD dan MSLQ.

Jadual 3: Nilai Alpha Cronbach bagi instrumen SKD dan MSLQ

\begin{tabular}{llll}
\hline Pemboleh ubah & No item & Bilangan item & Nilai Alpha Cronbach \\
\hline Daya tahan (SKD) & B1-B25 & 25 & 0.941 \\
Motivasi (MSLQ) & C1-C31 & 31 & 0.952 \\
\hline
\end{tabular}

Pengkaji melakukan prosedur analisis data secara dua kaedah iaitu analisis deskriptif dan analisis inferensi. Statistik deskriptif meliputi pengiraan min, kekerapan, sisihan piawai dan peratusan yang digunakan bagi mendapatkan maklumat mengenai latar belakang responden seperti jantina, umur, bidang pengajian dan lain-lain yang berkaitan dengan menggunakan aplikasi SPSS versi 23. Bagi menilai tahap daya tahan dan tahap motivasi yang berskala 7 mata, pengelasan skor min telah digunakan seperti dalam jadual 4. Hasil ujian normaliti menunjukkan taburan data dalam kajian ini adalah secara normal, maka prosedur analisis parametrik telah digunakan. Analisis inferensi digunakan untuk menghuraikan perbezaan dan hubungan antara pemboleh ubah. Ujian-t digunakan bagi mengenal pasti perbezaan pemboleh ubah berdasarkan faktor demografi responden. Manakala Korelasi Pearson $r$ digunakan bagi mengenal pasti hubungan antara pemboleh ubah iaitu hubungan antara daya tahan dengan motivasi pelajar sepanjang pembelajaran dalam talian. Tafsiran pekali korelasi menurut Cohen (1998) dinyatakan seperti di dalam jadual 5.

Jadual 4: Interpretasi min

\begin{tabular}{ll}
\hline Skor Min & Interpretasi \\
\hline 5.01 hingga 7.00 & Tinggi \\
3.01 hingga 5.00 & Sederhana \\
1.00 hingga 3.00 & Rendah \\
\hline
\end{tabular}

Sumber: Nik Mohd Rahimi (2004)

Jadual 5: Interpretasi korelasi

\begin{tabular}{ll}
\hline Pekali korelasi, $\mathbf{r}$ & Interpretasi \\
\hline 0.50 hingga 1.00 & Kuat \\
0.30 hingga 0.49 & Sederhana \\
0.10 hingga 0.29 & Lemah \\
\hline
\end{tabular}

Sumber: Cohen (1998)

\section{Hasil Kajian}

Hasil analisis menunjukkan terdapat tiga dapatan utama yang dibincangkan iaitu (i) tahap daya tahan dan tahap motivasi pelajar KUIM ketika mengikuti pembelajaran dalam talian sepanjang pandemik, (ii) perbezaan tahap daya tahan dan motivasi berdasarkan jantina dalam kalangan pelajar KUIM semasa 
pembelajaran dalam talian sepanjang pandemik dan (iii) hubungan antara daya tahan dengan motivasi pelajar KUIM sepanjang pembelajaran dalam talian semasa pandemik.

\section{Demografi responden}

Kajian ini telah melibatkan 278 orang pelajar KUIM sebagai sampel kajian. Daripada sampel tersebut, terdapat lebih ramai pelajar perempuan iaitu 219 orang $(78.8 \%)$ berbanding pelajar lelaki iaitu 59 orang (21.2\%). Lebih daripada separuh responden kajian ini berumur antara 18 hingga 21 tahun $(n=149$, 53.6\%). Hanya kurang dari 10 peratus $(n=23,8.3 \%)$ berumur antara 26 hingga 29 tahun. Agihan mengikut bangsa pula menunjukkan majoriti responden berbangsa Melayu iaitu ( $\mathrm{n}=269,96.8 \%)$, sementara majoriti responden $(\mathrm{n}=271,97.5 \%)$ berstatus bujang atau belum berkahwin.

Kebanyakan responden dalam kajian ini berada dalam kategori pendapatan keluarga B40 (isi rumah berpendapatan RM 4849 ke bawah) iaitu sebanyak 198 orang pelajar (71.2\%) dan hanya 11 orang (4\%) pelajar yang berada dalam kategori pendapatan keluarga T20 (isi rumah berpendapatan RM 10960 dan ke atas). Selain itu, majoriti responden tinggal di luar bandar ialah sebanyak 138 orang (49.6\%) dan hanya sebilangan kecil pelajar iaitu 35 orang $(12.6 \%)$ tinggal di pinggir bandar. Status pengajian responden adalah pada dua tahap pendidikan iaitu seramai 164 orang pelajar (59\%) sedang mengikuti pengajian diploma manakala 114 orang responden (41\%) sedang mengikuti pengajian ijazah sarjana muda.

Dapatan demografi juga menunjukkan tahap pencapaian akademik dalam kalangan responden adalah pada CGPA 3.01 hingga 3.50 iaitu sebanyak 124 orang pelajar (44.6\%), manakala hanya segelintir pelajar yang mempunyai tahap pencapaian akademik yang rendah iaitu CGPA 0 hingga 2.00, sebanyak 6 orang pelajar $(2.2 \%)$. Majoriti responden $(n=143,51.4 \%)$ menggunakan sumber internet dari data mudah alih dan 128 orang pelajar (46\%) yang menggunakan WiFi sebagai sumber internet semasa pembelajaran dalam talian sepanjang pandemik. Di samping itu, majoriti responden menggunakan komputer riba sebagai peranti semasa pembelajaran dalam talian $(n=240,86.3 \%)$ dan hanya sebilangan kecil yang menggunakan komputer meja dan tablet sebagai peranti pembelajaran secara dalam talian $(n=13,4.7 \%)$.

Jadual 6: Demografi responden

\begin{tabular}{llll}
\hline Pemboleh ubah & & Kekerapan $(\mathbf{F})$ & Peratusan $(\%)$ \\
\hline Jantina & Lelaki & 59 & 21.2 \\
Umur & Perempuan & 219 & 78.8 \\
& 18-21 tahun & 149 & 53.6 \\
Bangsa & 22-25 tahun & 106 & 38.1 \\
& 26-29 tahun & 23 & 8.3 \\
& Melayu & 269 & 96.8 \\
\multirow{5}{*}{ Taraf perkahwinan } & India & 4 & 1.4 \\
& Cina & 2 & 0.7 \\
\multirow{5}{*}{ Pendapatan keluarga } & Lain-lain & 3 & 1.1 \\
& Bujang & 271 & 97.5 \\
& Berkahwin & 7 & 2.5 \\
Kediaman & Duda/balu/berpisah & 0 & 0 \\
& M40 & 198 & 71.2 \\
& T20 & 69 & 24.8 \\
Pendidikan semasa & Bandar & 11 & 4.0 \\
& Luar bandar & 105 & 37.8 \\
Pencapaian akademik & Pinggir Bandar & 35 & 49.6 \\
& Diploma & 164 & 12.6 \\
& Ijazah Sarjana Muda & 114 & 59.0 \\
& 2-2.00 & 6 & 41.0 \\
& 2.01-2.50 & 11 & 2.2 \\
& & & 4.0 \\
\hline
\end{tabular}


DOI: https://doi.org/10.47405/mjssh.v6i10.1092

\begin{tabular}{llll}
\hline & $2.51-3.00$ & 54 & 19.4 \\
\multirow{4}{*}{ Sumber internet } & $3.01-3.50$ & 124 & 44.6 \\
& $3.51-4.00$ & 83 & 29.9 \\
\multirow{3}{*}{ Peranti } & Data mudah alih & 143 & 51.4 \\
& Pra bayar bulanan & 70 & 25.2 \\
& WiFi & 128 & 46.0 \\
& Komputer & 13 & 4.7 \\
& Komputer riba & 240 & 86.3 \\
& Tablet & 13 & 4.7 \\
& Telefon bimbit & 233 & 83.8 \\
\hline
\end{tabular}

\section{Tahap daya tahan dan motivasi pelajar}

Analisis deskriptif dijalankan ke atas kedua-dua pemboleh ubah untuk melihat nilai min, sisihan piawai dan skor min secara keseluruhan bagi tahap daya tahan dan tahap motivasi dalam kalangan sampel kajian. Jadual 7 menunjukkan min keseluruhan daya tahan bagi responden KUIM adalah tinggi iaitu 5.05. Hasil kajian ini juga menunjukkan bahawa dimensi bagi konstruk daya tahan yang tertinggi adalah falsafah persendirian $(m=5.34)$, diikuti oleh dimensi mempunyai makna $(m=5.07)$, dimensi ketabahan $(\mathrm{m}=5.01)$, dimensi ketenangan fikiran dan perasaan $(\mathrm{m}=4.92)$ dan terendah adalah dimensi kebergantungan kendiri $(\mathrm{m}=4.89)$.

Jadual 7: Tahap daya tahan pelajar sepanjang pembelajaran dalam talian

\begin{tabular}{llll}
\hline Dimensi & M & Sisihan Piawai & Tahap \\
\hline Kebergantungan kendiri & 4.89 & 1.03 & Sederhana \\
Mempunyai makna & 5.07 & 0.98 & Tinggi \\
Ketenangan fikiran dan perasaan & 4.92 & 1.02 & Sederhana \\
Ketabahan & 5.01 & 0.99 & Tinggi \\
Falsafah persendirian & 5.34 & 0.92 & Tinggi \\
\hline Keseluruhan daya tahan & $\mathbf{5 . 0 5}$ & $\mathbf{0 . 8 8}$ & Tinggi \\
\hline
\end{tabular}

Jadual 8 menunjukkan min keseluruhan motivasi sampel adalah tinggi iaitu $m=5$.33. Hasil kajian menunjukkan bahawa dimensi bagi konstruk motivasi yang tertinggi ialah dimensi motivasi ekstrinsik $(\mathrm{m}=5.78)$, diikuti oleh dimensi kawalan kepercayaan pembelajaran $(\mathrm{m}=5.52)$, dimensi nilai tugasan $(m=5.43)$, dimensi efikasi kendiri pembelajaran dan prestasi $(m=5.24)$, dimensi motivasi intrinsik $(\mathrm{m}=5.22)$ dan terendah adalah dimensi kebimbangan ujian $(\mathrm{m}=4.95)$.

Jadual 8: Tahap motivasi pelajar sepanjang pembelajaran dalam talian

\begin{tabular}{llll}
\hline Dimensi & M & Sisihan Piawai & Tahap \\
\hline Motivasi intrinsik & 5.22 & 1.02 & Tinggi \\
Motivasi ekstrinsik & 5.78 & 1.01 & Tinggi \\
Nilai tugasan & 5.43 & 0.93 & Tinggi \\
Kawalan kepercayaan pembelajaran & 5.52 & 0.98 & Tinggi \\
Efikasi kendiri pembelajaran dan prestasi & 5.24 & 0.99 & Tinggi \\
Kebimbangan ujian & 4.95 & 1.13 & Sederhana \\
\hline Keseluruhan motivasi & $\mathbf{5 . 3 3}$ & $\mathbf{0 . 8 2}$ & Tinggi \\
\hline
\end{tabular}

\section{Perbezaan daya tahan dan motivasi antara pelajar lelaki dan pelajar perempuan semasa pembelajaran dalam talian sepanjang pandemik}

Bagi menentukan kesignifikanan daya tahan pelajar KUIM berdasarkan jantina, hipotesis nul dibentuk dan diuji seperti berikut. 
Hipotesis Nul 1: Tidak terdapat perbezaan yang signifikan daya tahan berdasarkan jantina dalam kalangan pelajar Kolej Universiti Islam Melaka (KUIM) semasa pembelajaran dalam talian sepanjang pandemik Covid-19.

Jadual 9 menunjukkan skor min pelajar lelaki ialah $5.28(\mathrm{~N}=59, \mathrm{SP}=0.678)$ iaitu lebih tinggi berbanding skor min pelajar perempuan $4.98(\mathrm{~N}=219, \mathrm{SP}=0.915)$. Keputusan ujian-t menunjukkan nilai $\mathrm{t}$ ialah 5.10 dengan nilai signifikan adalah $0.025(\mathrm{P}<0.05)$. Keputusan ini gagal menerima hipotesis nul kerana terdapat perbezaan yang signifikan antara tahap daya tahan berdasarkan jantina dalam kalangan pelajar KUIM semasa pembelajaran dalam talian sepanjang pandemik. Ini bermakna daya tahan pelajar lelaki dan pelajar perempuan adalah berbeza sepanjang pembelajaran dalam talian semasa pandemik.

Jadual 9: Perbezaan daya tahan pelajar berdasarkan jantina $(n=278)$

\begin{tabular}{llllll}
\hline Pemboleh ubah & $\mathbf{N}$ & Min & SP & $\boldsymbol{t}$ & $\mathbf{P}$ \\
\hline Jantina & & & & 5.10 & 0.025 \\
\hline Lelaki & 59 & 5.28 & 0.678 & & \\
Perempuan & 219 & 4.98 & 0.915 & & \\
\hline
\end{tabular}

Seterusnya, bagi menentukan kesignifikanan motivasi pelajar KUIM berdasarkan jantina, hipotesis nul dibentuk dan diuji seperti berikut.

Hipotesis Nul 2: Tidak terdapat perbezaan yang signifikan antara tahap motivasi berdasarkan jantina dalam kalangan pelajar Kolej Universiti Islam Melaka (KUIM) semasa pembelajaran dalam talian sepanjang pandemik Covid-19.

Jadual 10 menunjukkan skor min pelajar perempuan ialah $5.35(\mathrm{~N}=219, \mathrm{SP}=0.832)$ iaitu lebih tinggi berbanding skor min pelajar lelaki $5.28(\mathrm{~N}=59, \mathrm{SP}=0.769)$. Keputusan ujian-t menunjukkan nilai t ialah 0.408 dengan nilai signifikan 0.523 ( $\mathrm{P}>0.05$ ). Keputusan ini menerima hipotesis nul kerana tidak terdapat perbezaan yang signifikan antara tahap motivasi berdasarkan jantina dalam kalangan pelajar KUIM semasa pembelajaran dalam talian sepanjang pandemik. Ini bermakna tiada perbezaan motivasi pelajar lelaki dan pelajar perempuan sepanjang pembelajaran dalam talian semasa pandemik.

Jadual 10: Perbezaan motivasi pelajar berdasarkan jantina $(n=278)$

\begin{tabular}{llllll}
\hline Pemboleh ubah & $\mathbf{N}$ & Min & SP & $\boldsymbol{t}$ & P \\
\hline Jantina & & & & 0.408 & 0.523 \\
\hline Lelaki & 59 & 5.28 & 0.769 & & \\
Perempuan & 219 & 5.35 & 0.832 & & \\
\hline
\end{tabular}

\section{Hubungan antara daya tahan dengan motivasi pelajar sepanjang pembelajaran dalam talian semasa pandemik}

Bagi menentukan kesignifikanan daya tahan dan motivasi pelajar KUIM, hipotesis nul dibentuk dan diuji seperti berikut.

Hipotesis Nul 3: Tidak terdapat hubungan yang signifikan antara daya tahan dengan motivasi dalam kalangan pelajar Kolej Universiti Islam Melaka (KUIM) semasa pembelajaran dalam talian sepanjang pandemik Covid-19.

Ujian pekali korelasi telah digunakan untuk menentukan hubungan antara daya tahan dengan motivasi pelajar. Hasil ujian menunjukkan bahawa terdapat hubungan yang signifikan dan positif antara daya tahan dengan motivasi pelajar dengan nilai $\mathrm{r}=0.696^{* *}$ dan $\mathrm{sig}=0.000(\mathrm{p}<0.05)$. Nilai $\mathrm{p}$ yang kurang daripada 0.05 menunjukkan terdapat hubungan yang signifikan antara dua pemboleh ubah yang berkaitan. Hal ini menunjukkan hipotesis nul adalah gagal diterima. Dapatan kajian juga menunjukkan 
semakin tinggi tahap daya tahan pelajar, semakin tinggi tahap motivasi pelajar. Jadual 11 menunjukkan hubungan daya tahan dengan motivasi pelajar.

Jadual 11: Hubungan daya tahan dengan motivasi pelajar $(\mathrm{n}=278)$

\begin{tabular}{llr}
\hline & \multicolumn{1}{c}{ Motivasi } \\
\hline & $\mathbf{R}$ & Sig. $\mathbf{P}$ \\
\cline { 2 - 3 } Daya tahan & $0.696^{* *}$ & 0.000 \\
\hline
\end{tabular}

Nota: **Pekali korelasi signifikan pada aras 0.05 (dua ekor)

\section{Perbincangan Kajian}

Dapatan kajian menunjukkan tahap daya tahan secara keseluruhan bagi pelajar KUIM adalah tinggi. Tiga dimensi daya tahan menunjukkan skor min berada pada tahap yang tinggi iaitu dimensi mempunyai makna, dimensi ketabahan dan dimensi falsafah persendirian. Dimensi ketenangan fikiran dan perasaan dan dimensi kebergantungan kendiri mempunyai skor min yang berada pada tahap sederhana. Kajian ini membuktikan pelajar KUIM mampu untuk memberikan makna bagi setiap peristiwa yang berlaku, mempunyai sikap ketabahan yang tinggi dalam menempuh dugaan dan mempunyai falsafah bahawa setiap individu mempunyai tahap penerimaan yang berbeza walaupun berkongsi pengalaman hidup yang sama (Wagnild \& Young, 1993). Kajian ini menyokong dapatan kajian Sobiroh dan Rosliza (2021) yang menunjukkan majoriti pelajar mampu berhadapan dan menangani masalah walaupun mempunyai ketahanan diri yang sederhana.

Bagaimanapun, dapatan kajian ini bertentangan dengan kajian Norasmah (2017) yang mendapati tahap daya tahan pelajar universiti awam dan universiti swasta di Malaysia berada pada tahap yang sederhana. Dapatan kajian ini jelas membuktikan bahawa bagi pelajar KUIM walaupun mereka harus menerima norma baharu dalam menjalani pembelajaran secara dalam talian, sesetengah mereka tidak merasa tergugat dengan permasalahan semasa pandemik, malah daya tahan mereka tetap tinggi. Dapatan kajian ini selari dengan kajian Burcu dan Derya (2020) terhadap pelajar IPT di Turki yang merumuskan ketahanan psikologi pelajar universiti semasa pandemik adalah tinggi. Boleh diandaikan terdapat usaha pelajar di IPT dalam menerima norma baharu dalam pembelajaran lebih-lebih lagi semasa musim pandemik. Namun begitu, masih terdapat keperluan untuk melihat tahap daya tahan pelajar pada masa akan datang memandangkan situasi pandemik yang berpanjangan berisiko menjadikan pelajar berada dalam fasa kelesuan (burn out) (Shakir et al., 2020).

Seterusnya, dapatan kajian menunjukkan tahap motivasi secara keseluruhan bagi pelajar KUIM adalah tinggi semasa pembelajaran dalam talian sepanjang pandemik Covid-19. Lima dimensi motivasi (dimensi motivasi intrinsik, dimensi motivasi ekstrinsik, dimensi nilai tugasan, dimensi kawalan kepercayaan pembelajaran dan dimensi efikasi kendiri pembelajaran dan prestasi) adalah pada tahap yang tinggi. Manakala, hanya satu sahaja dimensi motivasi iaitu dimensi kebimbangan ujian berada pada tahap yang sederhana. Hasil kajian ini membuktikan pelajar KUIM bermotivasi tinggi untuk belajar walaupun harus menjalani pembelajaran secara dalam talian sepanjang pandemik. Dapatan ini memperkukuhkan dapatan kajian yang dijalankan oleh Rosmilawati, Raja Ahmad dan Mohd Sahril (2020) yang mendapati tahap motivasi pelajar yang mengikuti pembelajaran dalam talian adalah tinggi. Motivasi pelajar yang tinggi menunjukkan mereka berminat mengikuti pembelajaran secara dalam talian (Abdul Aziz \& Aida, 2020).

Di samping itu, kajian ini mendapati tahap daya tahan semasa pembelajaran dalam talian sepanjang pandemik adalah berbeza antara pelajar lelaki dan perempuan. Malah tahap daya tahan antara pelajar lelaki dan perempuan adalah ketara. Tahap daya tahan pelajar lelaki lebih tinggi berbanding daripada pelajar perempuan. Dapatan kajian ini bertepatan dengan kajian yang dijalankan oleh Irmohizam dan Hussin (2016) yang mendapati terdapat perbezaan yang signifikan tahap daya tahan antara jantina, serta pelajar lelaki mempunyai daya tahan yang lebih tinggi berbanding pelajar perempuan. Dapatan kajian berkaitan daya tahan pelajar universiti di Turki semasa pandemik juga menunjukkan pelajar lelaki mempunyai daya tahan yang lebih tinggi berbanding pelajar perempuan (Burcu Karasar \& Derya Canli, 2020). 
Dapatan hasil kajian berkaitan tiada perbezaan tahap motivasi semasa pembelajaran dalam talian sepanjang pandemik antara pelajar lelaki dan perempuan juga menyokong dapatan kajian lepas (Wan Naliza \& Siti Mistima, 2020). Tahap motivasi antara pelajar lelaki dan pelajar perempuan tidak ketara. Namun dapatan ini bertentangan dengan beberapa dapatan lain seperti dapatan kajian yang dijalankan Mohd Taufiq (2021) yang mendapati terdapat perbezaan tahap motivasi pelajar lelaki dengan pelajar perempuan di IPT yang telah mempengaruhi prestasi pembelajaran mereka.

Dapatan berkaitan hubungan positif dan kuat antara daya tahan dengan motivasi pelajar sepanjang pembelajaran dalam talian semasa pandemik menunjukkan bahawa semakin tinggi tahap daya tahan seseorang pelajar, semakin tinggi motivasi mereka sepanjang pembelajaran dijalankan. Dapatan kajian ini selari dengan kajian Masron et al. (2021) juga mendapati terdapat hubungan yang positif antara motivasi dengan ketahanan diri pelajar. Ketahanan diri pelajar yang kuat mampu meningkatkan motivasi pelajar untuk belajar walaupun semasa pandemik (Scott et al., 2020). Jelas bahawa daya tahan dan motivasi adalah faktor penting dalam mencapai tujuan pembelajaran walaupun pelajar harus berhadapan dengan norma baharu dalam sistem pendidikan.

\section{Kesimpulan}

Kajian ini telah mengenal pasti tahap daya tahan dan motivasi dalam kalangan pelajar di sebuah institusi pengajian tinggi iaitu Kolej Universiti Islam Melaka. Kajian turut meninjau hubungan daya tahan dengan motivasi pelajar KUIM sepanjang pembelajaran dalam talian semasa pandemik. Dapatan kajian menunjukkan pelajar Kolej Universiti Islam Melaka (KUIM) mempunyai tahap daya tahan dan tahap motivasi yang tinggi sepanjang pembelajaran dalam talian semasa pandemik dan terdapat hubungan antara daya tahan dengan motivasi pelajar.

Beberapa limitasi telah dikenal pasti sepanjang kajian ini dijalankan antaranya ialah kesukaran mendapatkan responden yang tinggal di rumah semasa pandemik dan bilangan responden yang lebih ramai memandangkan kaedah bagi mengumpul data ini adalah melalui edaran soal selidik secara dalam talian menggunakan Google Form. Selain itu, dapatan kajian juga bergantung kepada kejujuran responden menjawab soalan yang dikemukakan dan penyelidik mengandaikan responden memberi jawapan yang tepat secara ikhlas dan jujur. Kajian ini hanya melibatkan pelajar diploma dan ijazah sarjana muda. Oleh itu, dicadangkan bahawa kajian lanjutan dijalankan ke atas pelajar dari pelbagai bidang pengajian dan tahap pendidikan. Kajian lanjutan perlu memperluaskan skop kajian kepada pelajar kolej universiti yang lain yang mempunyai pelbagai etnik, peringkat umur, tahap pendidikan serta membuat perbandingan daya tahan dan motivasi antara pelajar dari IPT swasta dan IPT awam. Tambahan lagi, kajian selanjutnya masih perlu dijalankan bagi melihat tahap motivasi berikutan terdapat kemungkinan pelajar berjaya beradaptasi dan meningkatkan tahap motivasi atau sebaliknya akibat daripada pendedahan terhadap cabaran kehidupan semasa pandemik yang berterusan.

Kajian ini telah menyumbang dalam meningkatkan kefahaman dan ilmu sedia ada berkaitan tahap daya tahan dan motivasi pelajar iaitu dua faktor utama yang menyumbang kepada pembelajaran (Aisyah et al., 2017; Nor Fadilah \& Siti Mistima, 2020). Pihak pengurusan KUIM perlu terus merancang untuk membentuk modul berkaitan kecemerlangan pembelajaran dalam talian bagi meningkatkan daya tahan dan motivasi pelajar khususnya pelajar tahun pertama yang akan mengikuti pembelajaran secara dalam talian atau hybrid buat pertama kali. Kursus dan bengkel pengajaran kepada ahli akademik juga perlu memberi penekanan kepada cara fasilitator memberi sokongan dan meningkatkan motivasi pelajar semasa mengendalikan pembelajaran dalam talian serta memberikan maklum balas dengan cara yang berkesan dan konsisten (Martin, 2002). Terdapat keperluan untuk program pengukuhan kemahiran ICT bagi memastikan pelajar kurang terdedah dengan isu dan permasalahan berkaitan kemahiran menggunakan teknologi agar mereka dapat melalui proses pembelajaran dengan baik tanpa pelbagai halangan (Ida Faridah et al., 2020). Implikasi kajian ini juga menggalakkan pihak KUIM untuk memastikan pelajar melibatkan diri dalam aktiviti perbincangan bersama rakan kerana sokongan rakan sebaya adalah peramal kuat kepada daya tahan dan motivasi akademik pelajar (Mc Dermott, 2017; Nur Afiqah \& Che Nooryohana, 2020). 


\section{Rujukan}

Abdul Aziz Ishak \& Aida Zuraina Mir Ahmad Talaat. (2020). Pembelajaran Atas Talian: Tinjauan Terhadap Kesediaan dan Motivasi dalam kalangan Pelajar Diploma Logistik dan Pengurusan Rantaian Bekalan, Politeknik Seberang Perai, Pulau Pinang. Jurnal Dunia Pendidikan, 2(4), 6882.

Aisyah Sjahrony, Maimum Aqsha Lubis, Harun Baharudin \& Mohd Sham Kamis. (2017). Kepentingan Pembelajaran Motivasi Bahasa Arab Dalam Kalangan Pelajar IPTA dari Perspektif Sorotan Kajian. ASEAN Comparative Education Research Journal on Islam and Civilization, 1(2), 102-112.

American Psychological Association. (2014). The road to resilience. Washington, DC: American Psychological Association http://www.apa.org/helpcenter/road-resilience.aspx.

Barbara, R. (2018). The relationship between resilience and motivation: Concepts, Research and Outcomes. Resilience in aging, 221-224.

Benson, P.L. (2002). Adolescent development in sosial and comunity context: A program of research. New Directions For Youth Development, 95.

Burcu, K. \& Derya, C. (2020). Psychological Resilience and Depression During the Covid-19 Pandemic in Turkey. Psychiatria Danubina, 32(2), 273-279.

Chua, Y. P. (2014). Kaedah Penyelidikan Edisi Ketiga. Selangor: McGraw-Hill Education (Malaysia) Sdn. Bhd.

Creswell, J. W. (2015). Educational Research Planning, Conducting, and Evaluating Quantitative and Qualitative Research. Fourth edition. Boston: Pearson Education, Inc.

Harsela, K., \& Asih, E. C. (2020). The level of mathematical resilience and mathematical problemsolving abilities of 11th grades sciences students in a senior high school. Journal of Physics Conference Series, 1521(032053).

Ida Faridah, Febi Ratna Sari, Tri Wahyuningsih, Fitri Putri Oganda \& Untung Rahardja. (2020). Effect Digital Learning On Student Motivation During Covid-19. The 8th International Conference on Cyber and IT Service Management On Virtual.

Irmohizam Ibrahim \& Muhammad Hussin. (2016). Tahap Daya Tahan Dalam Kalangan Pelajar IPTA di Malaysia dan di Luar Negara. Jurnal Personalia Pelajar, 19(1), 75-85.

Kamaruddin Hussin. (1993). Pengajaran lisan: Kemahiran mendengar dan bertutur. Kuala Lumpur: Kumpulan Budiman Sdn. Bhd.

Krajcie \& Morgan. (1970). Determining Sampel Size for Research Activities. Educational and Psychological Measurement, 30, 607-610.

Letchumanan Shanmugam, Siti Fatimah Yassin \& Fariza Khalid. (2019). Enhancing Students' Motivation to Learn Computational Thinking through Mobile Application Development Module (M-CT). International Journal of Engineering and Advanced Technology, 8(5), 1293-1303.

Martin, A. J. (2002). Motivation and academic resilience: Developing a model of student enhancement. Australian Journal of Education, 46, 34-49.

Masron Mensih, Fauziah Ibrahim \& Nazirah Hassan. (2021). Hubungan antara motivasi pencapaian, kecerdasan emosi dan ketahanan diri dalam kalangan mahasiswa kerja sosial. Journal of Social Sciences and Humanities, 18(1), 37-48.

Mc Dermott, E. R., Donlan, A. E., Anderson, S., \& Zaff, J.F. (2017). Self control and adolescent internalizing and externalizing problems: Neighborhood-based differences. Journal of Community Psychology, 45(3), 297-314.

Mohd Taufiq Syakirin. (2021). Tahap motivasi intrinsik dan pencapaian pelajar dalam pembelajaran kimia topik gas berasaskan permainan 'Jejak Rembo'. Jurnal Penyelidikan Dedikasi, 12, 117 144.

Molly, C. D., Heather, M. K., Blaine, L. B. \& Steven, J. K. (2020). Assesing motivation and learning strategy usage by dually enrolled students. Smart Learning Environments Springer Open Journal, $7(22), 1-19$.

Muhammad Izzat Mailis, Zuriani Hanim Zaini \& Nur Hafizaliyana Hassan. (2020). Persepsi Pelajar Kolej Universiti Islam Melaka Terhadap Pelaksanaan Pembelajaran Secara Atas Talian Dalam Era Pandemik Covid-19. Jurnal Kesidang, 5, 88-99. 
Munirah Salleh, Mohd Faisal Jamaludin, Nor Syaheeda Mohd Safie \& Julia Mohd Yusof. (2021). Tinjauan keberkesanan pembelajaran secara dalam talian ketika pandemik Covid-19: Perspektif pelajar Sains Kejuteraan Politeknik Ibrahim Sultan. Jurnal Dunia Pendidikan, 3(1), 374-384.

Norasmah Othman. (2017). Daya tahan pelajar universiti awam dan swasta. Jurnal Pendidikan Malaysia, 42(1), 77-86.

Norfadilah Mat \& Siti Mistima Maat. (2020). Faktor dan Implikasi Daya Tahan dalam Pembelajaran Matematik: Sorotan Literatur Bersistematik. Malaysian Journal of Social Sciences and Humanities, 5(12), 90-105.

Nur Afiqah Ab Latif \& Che Nooryohana Zulkifli. (2020). Peer-tutoring: An approach to enhance students' motivation to learn English. Sains Insani, 5(2), 25-31.

Pintrich, P. R., Smith, D. A. F., Garcia, T., \& McKeachie, W. J. (1991). A manual for the use of the Motivated Strategies for Learning Questionnaire (MSLQ). Ann Arbor: National Center for Research to Improve Postsecondary Teaching and Learning, The University of Michigan.

Richardson, G. E. (2002). The metatheory of resilience and resiliency. Journal of Clinical Psychology, $58(3), 307-321$.

Rios, T. (2019). The relationship between students'personalities and their perception of online course experiences. Journal of Educators Offline, 16(1), 1-11.

Rocio, G. M., Antonio, Z., Paula, R. G. \& Rocio, G. (2018). Optimism and resilience among university students. Asociacion INFAD.

Rosmilawati Ab Rahman, Raja Ahmad Syawal Raja Musa \& Mohd Sahril Mohd Fouzi. (2020). Kesediaan dan motivasi pelajar Kolej Komuniti Negeri Perak untuk menghadapi norma bahari sewaktu pandemik coronavirus disease (COVID-19): Pembelajaran secara atas talian. Politeknik \& Kolej Komuniti Journal of Social Sciences and Humanities, 5(1), 28-40.

Sah Alam, S. N., Hassan, M.S.,Sultan Mohideen R.,Ramlan, A.F., \& Mohd Kamal, R. (2020). Online distance learning readiness durinh covid-19 outbreak among undergraduate students. International Journal of Academic Research in Business \& Social Sciences, 10(5), 642-657.

Sallehudin, N.N. \& Zakaria, E. (2017). Sikap dan keupayaan pelajar dalam menyelesaikan masalah matematik bukan rutin. Persidangan Antarabangsa Sains Sosial \& Kemanusiaan.

Scott Compton, Shiva Sarraf-Yazdi, Felicia Rustandy \& Lalit Kumar Radha Krishna. (2020). Medical students preference for returning to the clinical setting during the Covid-19 pandemic. Medical Education, 1-8.

Shakir, h.J. Cappuzzo, J.M., Shallwani, H.,Kwasnicki, A., Bullis, C., Wang, J. Hess, R.M. \& Levy, E.I. (2020). Relationship of grit and resilience to burnout among U.S neurosurgery residents. World Neurosurgery, 134, 224-236.

Sharifah Akmam Syed Zakaria. (2005). Panduan dan Strategi Motivasi Diri. Kuala Lumpur: Utusan Publications \& Distributors Sdn Bhd.

Sobiroh Muhamad Puzi \& Rosliza Ahmad. (2020). Resiliensi, Religiosti dan depresi dalam kalangan mahasiswa muslim: Satu tinjauan di universiti tempatan. Jurnal Pembangunan Sosial, 23, 1-23.

Wagnild, G.M. \& Young, H.M. (1993). Development and Psychometric Evaluation of Resilience Scale. Journal of Nursing Measurement, 1(2):165-178.

Wan Naliza Wan Jaafar \& Siti Mistima Maat. 2020. Hubungan antara motivasi dengan pencapaian matematik dalam kalangan murid sekolah luar bandar. Jurnal Pendidikan Sains \& Matematik Malaysia, 10(1), 39-48.

Warren, J.M. \& Hale, R.W. (2020). Predicting Grit and Resilience: Exploring College Students' Academic Rational Beliefs. Journal of College Counseling.

Zaliza Mohamad Nasir \& Zaitul Azma Zainon Hamzah. (2014). Sikap dan motivasi pelajar terhadap pembelajaran Bahasa Melayu. Procedia-Social and Behavioral Sciences, 134, 408-415. 